\title{
水素-酸素-希釈ガス予混合乱流火资の局所燃焼速度特性に関する実験的検討*
}

\section{An Experimental Study on Local Flame Displacement Velocity of Hydrogen-Oxygen-Dilution Gas Premixed Turbulent Flames}

\author{
Masaya NAKAHARA *1, Shohei NISHIBE, Jun HASHIMOTO and Fumiaki ABE \\ ${ }^{* 1}$ Ehime University, Department of Mechanical Engineering \\ Bunkyo-cho 3, Matsuyama, 790-8577 Japan
}

This experimental study was performed to investigate directly the local flame properties of turbulent propagating flames at the same weak turbulence condition, in order to clarify basically the influence of the addition of dilution gas to hydrogen mixtures on its local burning velocity. The mixtures having nearly the same laminar burning velocity with different dilution gas types and equivalence ratios were prepared. A two-dimensional sequential laser tomography technique was used to obtain the relationship between the flame shape and the flame displacement in a constant-volume vessel. The local flame displacement velocity $S_{F}$, curvature and stretch of turbulent flames were quantitatively measured as some of the key parameters of local flame properties on turbulent flames. Additionally, the Markstein number $M a$ was obtained from outwardly propagating spherical laminar flames, in order to examine the effect of positive stretch on burning velocity. It was found that the trends of the mean values of measured $S_{F}$ with respect to dilution gas types and equivalence ratios corresponded well its turbulent burning velocity. The trend of the obtained $M a$ could explain the $S_{F}$ of turbulent flames only qualitatively. The local burning velocity at the part of turbulent flames with positive stretch and curvature due to the $M a, S_{L t}$, attempted to be estimated quantitatively. As a result, a quantitative relationship between the estimated $S_{L t}$ and the $S_{F}$ at positive stretch and curvature of turbulent flames could be observed only for mixtures with $L e>1$ or $M a>0$, regardless of dilution gas types.

Key Words : Internal Combustion Engine, Premixed Combustion, Hydrogen-Oxygen Combustion, Dilution Gas, Local Burning Velocity, Markstein Number, Lewis Number, Preferential Diffusion

\section{1. 緒言}

水素一酸素燃焼は，二酸化炭素・未燃炭化水素・窒素酸化物フリ一燃焼であり，環境負荷低減を目指した究極 的な燃焼技術の一つである. しかしながら, 実用的には燃焼温度制御のために適切な希釈ガスが必要になる(1)(3). 各種燃焼機器の性能は燃焼速度特性に支配され, さらに一般的な燃焼機器が高負荷燃焼化のために乱流燃焼場を 利用していることから，水素一酸素一希釈ガス混合気の乱流燃焼速度に関する知見およびその予測モデルの構築 は次世代水素燃焼機器を開発するためには必要不可欠である.

さらに，水素の利用で潜在化する水素漏洩に伴う火災爆発事故を抑制・防止するための一つの技術として，希 䣋ガスを利用すること (4)(5)が期待されている. これら防止技術を確立する上でも, 火災等が発生した場にガス流動 が存在し乱流燃焼化していることも想定されるため，希釈ガスが乱流燃焼特性に及ぼす影響を解明することは重 要な課題である.

\footnotetext{
* 原稿受付 2011 年 8 月 14 日

${ }^{* 1}$ 正員, 愛媛大学大学院理工学研究科（干790-8577 愛媛県松山市文京町 3 番）

*2 学生員, 愛媛大学大学院理工学研究科

*3 正員, 津山工業高等専門学校機械工学科（干708-8509 岡山県津山市沼 624-1）

E-mail: mnakahara@eng.ehime-u.ac.jp
} 
一方，著者らは既報(6)で，層流燃焼速度を揃えた水素一酸素一希勫ガス混合気の乱流燃焼速度特性について検 討した，その結果，希薄混合気では，希釈ガスの種類により，乱流燃焼速度特性に与える影響が異なることを明 らかにした，そこでは，希勫ガスの分子拡散特性に起因した選択拡散効果により，乱れにより湾曲した火炎面で の実質的な燃焼速度である局所燃焼速度の平均值が層流燃焼速度から変化し, 乱流燃焼速度特性に大きく影響を

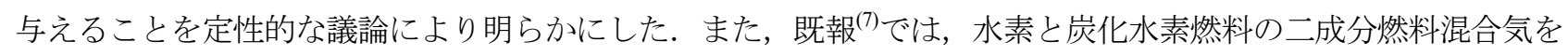
対象に燃料の分子拡散特性がごのように影響を与えるかに着目し, この乱流燃焼場で重要となる局所燃焼速度を 直接的な手法で詳細な検討を行った。

本研究では, 希釈ガスが乱流燃焼場で重要な局所燃焼速度特性に与える影響を詳細に検討するために, 層流燃 焼速度を揃えた当量比が 0.5 と 0.7 の希薄混合気に加え, 量論比の 1.0 の水素一酸素一希釈ガス混合気を対象に, 乱流火炎の局所伝ぱ特性を直接観測し定量的に評価する，希釈ガスとしては，内燃機関を想定した場合に理論熱 効率の向上が望めるアルゴンおよびヘリウムを, 比較のために一般的な窒素も対象にする. ここでは, しわ状層 流火炎が存在するような比較的乱れの弱、領域での予混合乱流伝ぱ火炎を対象に, 局所火炎伝ぱ特性を二次元で はあるが連続断層写真として観測し，局所火炎燃焼特性を検討するために火炎変位速度および火炎形状を定量的 に議論する.さらに, 局所の火炎伸長が乱流火炎の局所燃焼速度特性に与える影響を検討するために, 外向きに 伝ぱする球状層流火炎から求まる燃焼速度の火炎伸張に対する感度を表す Markstein 数を推定し, 乱流火炎から 得られた火炎変位速度との関係および乱流火炎の局所燃焼速度に与える定量的な影響を明らかにする.

\section{2. 実験装置および方法}

\section{$2 \cdot 1$ 実験方法}

燃焼実験には既報 7 (8) と同様の燃焼器および二次元連続火炎断層写真撮影システムを使用した。燃焼器は, 図 1 に示す内径が約 $100 \mathrm{~mm}$ の球形に近い定容燃焼器で, 向かい合う 4 面に直径 $85 \mathrm{~mm}$ の観測空, 他の 2 面には直径 $90 \mathrm{~mm}$ の多孔板を有し，その後方の遠心ファンを回転させることにより燃焼室中心部に概ね等方的な定常乱れ場 を発生できる. 火炎断層写真撮影システムは, 光源に連続発振 Nd:YAG レーザ（第二高調波 $532 \mathrm{~nm}$, 出力 $5 \mathrm{~W}$ ) を用い，三枚のシリンドリカルレンズにてシート光を燃焼室に照射でき，混合気に添加された二酸化チタン粒子 $(0.03 \sim 0.05 \mu \mathrm{m})$ の散乱光を高速度カメラ（512×512 画素，8bit，2000 FPS，露光時間 $18 \mu \mathrm{s} ）$ で撮影できる. な お, 本研究は二次元の撮影ではあるが, 火炎の三次元的挙動を極力排除寸るため, 燃焼室内に照射されるシート 光は，点火栓の中心位置を通過するようにしている．また， 1 画素の大きさは実像上で $0.12 \mathrm{~mm}$ である.

実験は，各混合気（表 1 参照）を大気圧充填し，所定の乱れ強さ $u^{\prime}$ の下で，燃焼室の中心で火花点火し外向 きに伝ぱする火炎を観測した．なお，点火エネルギーは，約 $2.0 \mathrm{~J}$ とた．乱流火炎の撮影は，既報(7)(8) と同様に ファン回転数を $1000 \mathrm{rpm} と し$, すなわち $u^{\prime}$ が $0.35 \mathrm{~m} / \mathrm{s}$ (ヘリウムの場合 : $0.47 \mathrm{~m} / \mathrm{s}$ ), または $u$ ' $S_{L 0}$ では 1.4 (ヘリ ウムの場合 : 1.8) となる乱れ場で実施した. 表 1 に, 既報(の) と同様に混合気の動粘度を考慮した非燃焼場での乱流

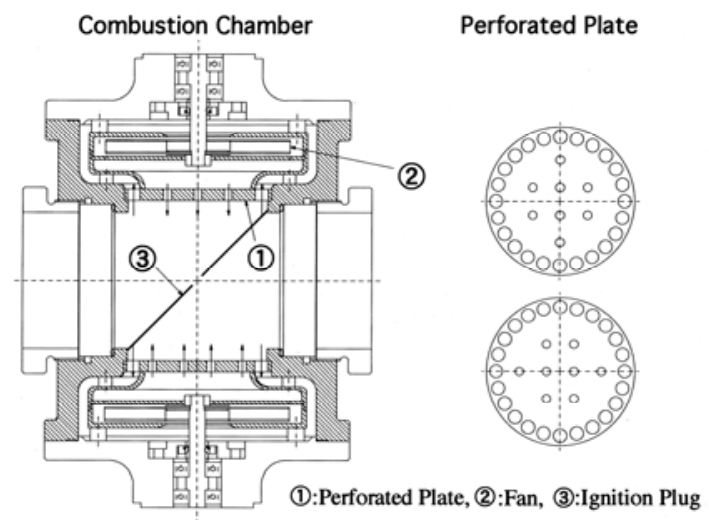

Fig. 1 Cross-sectional view of combustion chamber 
Table 1 Properties of mixtures and test condition

\begin{tabular}{|c|c|c|c|c|c|c|c|c|c|c|c|c|c|c|}
\hline \multirow{2}{*}{ Mixture } & \multirow{2}{*}{$\phi$} & \multicolumn{3}{|c|}{ Components [mol] } & \multirow{2}{*}{$\begin{array}{r}S_{L 0} \\
\mathrm{~cm} / \mathrm{s} \\
\end{array}$} & \multirow{2}{*}{$\begin{array}{c}a_{0} \\
\mathrm{~mm}^{2} / \mathrm{s} \\
\end{array}$} & \multirow{2}{*}{$\begin{array}{c}v \\
\mathrm{~mm}^{2} / \mathrm{s} \\
\end{array}$} & \multirow{2}{*}{ Le } & \multirow{2}{*}{$\begin{array}{c}T_{P} \\
\mathbf{K} \\
\end{array}$} & \multirow{2}{*}{$\frac{D_{D}}{D_{D, N 2}}$} & \multicolumn{4}{|c|}{ Fan Speed 1000 rpm } \\
\hline & & $\mathbf{H}_{2}$ & $\mathbf{O}_{2}$ & DilutionGas & & & & & & & $u^{\prime} / S_{L 0}$ & $L_{f} / \eta_{0}$ & $\mathrm{Da}_{l}$ & $\boldsymbol{R e}_{1}$ \\
\hline H05-25N & 0.5 & 1.0 & 1.0 & $\mathrm{~N}_{2} 6.63$ & 24.9 & 29.5 & 17.2 & 0.41 & 1221 & 1.00 & 1.41 & 23.6 & 16.7 & 57.1 \\
\hline H07-25N & 0.7 & 1.0 & 0.7 & $\mathrm{~N}_{2} 6.14$ & 25.1 & 30.4 & 17.4 & 0.42 & 1309 & 1.00 & 1.40 & 23.1 & 16.5 & 56.5 \\
\hline H10-25N & 1.0 & 1.0 & 0.5 & $\mathrm{~N}_{2} 5.66$ & 24.8 & 31.4 & 17.6 & - & 1402 & 1.00 & 1.42 & 22.1 & 15.5 & 55.9 \\
\hline H05-25A & 0.5 & 1.0 & 1.0 & Ar 9.20 & 25.3 & 29.3 & 15.3 & 0.39 & 1279 & 0.98 & 1.38 & 24.1 & 17.4 & 64.1 \\
\hline H07-25A & 0.7 & 1.0 & 0.7 & Ar 8.64 & 25.4 & 30.0 & 15.4 & 0.40 & 1367 & 0.98 & 1.38 & 23.6 & 17.1 & 63.8 \\
\hline H10-25A & 1.0 & 1.0 & 0.5 & Ar 8.00 & 25.1 & 30.9 & 15.5 & - & 1470 & 0.99 & 1.40 & 22.7 & 16.3 & 63.4 \\
\hline H05-25H & 0.5 & 1.0 & 1.0 & He 10.30 & 25.7 & 151.9 & 82.0 & 1.11 & 1197 & 2.94 & 1.81 & 5.0 & 2.8 & 16.8 \\
\hline
\end{tabular}

特性值を示す. 表 1 中, $u$ ' は乱れ強さ(ガス流速変動の二乗平均值), $S_{L 0}$ は層流燃焼速度, $\eta_{0}$ は予熱帯厚さ $\left[=a_{0} / S_{L 0}\right]$, $L_{f}$ は縦方向積分尺度, $D a_{l}$ はダムケラ一数 $\left[=L_{f} / u^{\prime} \cdot S_{L 0} / \eta_{0}\right], R e_{l}$ は $L_{f}$ に基づくレイノルズ数 $\left[=L_{f} \cdot u^{\prime} / v\right], a_{0}$ は熱拡 散係数およびvは動粘性係数である. また, 乱流火炎の連続断層写真撮影は各混合気に対して 10 回ずつ行った. また Markstein 数の算出のために，静止混合気中を伝ぱする層流火炎の撮影は 5 回ずつ実施した.

\section{$2 \cdot 2$ 混合気}

本研究では, 希釈ガス ${ }^{(6)}$ には，一般的な窒素 $\left(\mathrm{N}_{2}\right)$ に加え, 窒素とほぼ同等の拡散特性を有するアルゴン $(\mathrm{Ar})$ およ び拡散速度が大きなへリウム $(\mathrm{He})$ を用いた。 実験に用いた水素一酸素一希釈ガス混合気を表 1 に示す。各混合気 は，水素一酸素混合気への希釈ガス量を調整することにより層流燃焼速度 $S_{L 0}$ を $25 \mathrm{~cm} / \mathrm{s}$ にほぼ揃えた当量比㛒 0.5, 0.7 および 1.0 の人工的に作成した混合気である. 表 1 に示すように，層流燃焼速度を揃えた混合気を用いる ことにより化学平衡計算による定圧断熱然焼温度 $T_{p}$ が概ね等しくなり, 火炎面形状や火炎面近傍のガス流動に影 響を与える可能性のある浮力や熱膨張の影響を平準化できる. なお，希釈ガスをへリウムにした場合，饾 0.7 お よび 1.0 の混合気は，同一点火エネルギーでは作成できなかった。ここで，表 1 中，Le は不足成分の拡散係数 $D_{d}$ に基づくルイス数 $\left[=a_{0} / D_{d}\right]$ を表す. また， $D_{D}$ は二成分系拡散係数に基づく多成分系拡散係数 ${ }^{(6)(9)}$ から算出した各混 合気の希釈ガスの拡散係数であり， $D_{D, N 2}$ は同一 $\phi$ 窒素を希釈ガスとした混合気での窒素の拡散係数を表す。な お， $S_{L 0}$ は，既報 ${ }^{(6)}{ }^{(10)}$ と同様に，点火後燃焼初期の燃焼室内圧力上昇が $0.01 \sim 0.02 \mathrm{MPa}$ 範囲での圧力上昇率 $d p / d t$ から算出 ${ }^{(11)}$ した.

図 2 に, 使用した混合気の同一ファン回転速度 $1000 \mathrm{rpm}\left(\mathrm{N}_{2} \& \mathrm{Ar}: u^{\prime} / S_{L 0}=1.4, \mathrm{He}: u^{\prime} / S_{L 0}=1.8\right)$ での 燃焼速度 $S_{T}$ の変化を示す. 図 2 中, 既報 ${ }^{(7)}$ の窒素を希釈ガスとした $S_{L 0}$ を $25 \mathrm{~cm} / \mathrm{s}$ に揃えた $\phi=0.8$ と 1.2 の水素混合 気の結果も合わせて示す. 図 2 から, 窒素と同等の拡散特性を有するアルゴンほほぼ等しい $S_{T}$ 特性を示す.一方,

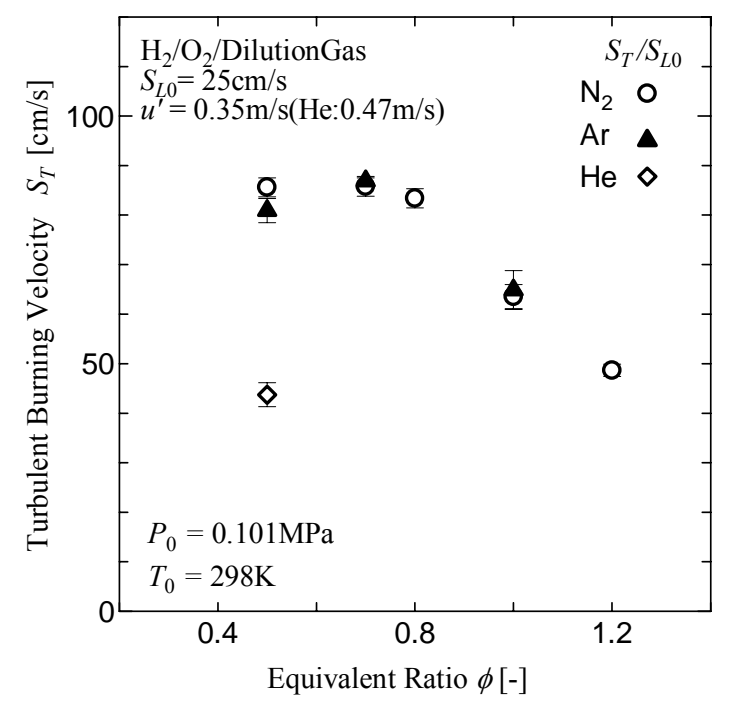

Fig. 2 Variation of $S_{T}$ with $\phi$ and dilution gas types at $u^{\prime} / S_{L 0}=1.4$ for $\mathrm{N}_{2}$ and $\mathrm{Ar}, u^{\prime} / S_{L 0}=1.8$ for He.

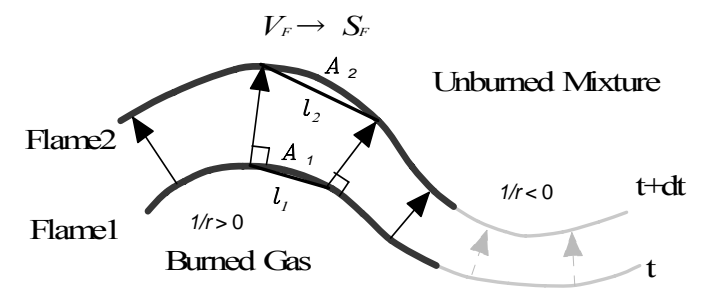

Fig. 3 Schematic illustration of determinations of local flame displacement velocity $S_{F}$ and flame stretch $K_{T}$ of turbulent flames. 
窒素より拡散速度が大きなへリウムは, 相対的な乱れ強さが大きいにも関わらず $S_{T}$ が著しく低下することがわか

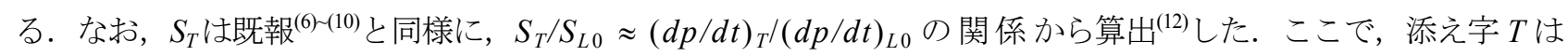
乱流燃焼，L0 は層流燃焼を表す。

\section{$2 \cdot 3$ 局所火炎伝ぱ特性解析方法}

本研究では, 局所火炎燃焼特性として, 既報(7)(8) と同様の手法で, まず火炎形状特性として局所火炎曲率 $1 / r$ お よび火炎伝ぱ特性として局所燃焼速度に相当寸る換算局所火炎変位速度 $S_{F}$ の定量化を行った.

ここでは, 解析法の概要を次に示す. まず得られた連続火炎断層写真から着目している火炎面を離散点として 検出し, 各解析点における $1 / r$ を算出寸る. 本解析では, 未燃混合気側に凸な火炎曲率を正とした. 次に, 図 3 に示すように, 着目している火炎面 1 と, $0.5 \mathrm{~ms}$ 後の火炎面 2 から, 局所火炎伝ぱ速度(既然ガスに関する局所火 炎変位速度) $V_{F}$ を算出寸る. ここで，二枚の画像の時間間隔が短いことから，火炎素面の移動方向は，火炎面 1 上 の解析点から法線ベクトル方向に火炎が伝ぱしたと仮定し, 法線ベクトルと火炎面 2 が交わる点までの距離から $V_{F}$ を算出した. さらに, 換算局所火炎変位速度 (未燃混合気に関する局所火炎変位速度) $S_{F}$ は次式により求めた.

$$
S_{F}=\left(\rho_{b} / \rho_{u}\right) \cdot V_{F}
$$

ここで, $\rho_{\mathrm{b}}, \rho_{\mathrm{u}}$ は各々既然ガス, 未燃混合気の密度であり, $\rho_{\mathrm{b}}$ は表 1 の化学平衡計算による $T_{p}$ にり算出した. なお，既報(7)(8)で議論したように，乱流火炎から得られた $S_{F}$ は，本実験では等方的な定常乱れ場を使用している こと等から, 概社乱流火炎の局所燃焼速度特性を評価できる值と考えられる. しかしながら, 正確な局所燃焼速 度の算出には火炎面近傍の流れ場を把握することが必要 ${ }^{(13)}$ であるが, 本研究での乱れ場の計測は非燃焼場のみで あり， $S_{F}$ には考慮していない.

さらに, 火炎伝ぱ進行とともに上昇する燃焼室内圧力や火炎サイズの影響を取り除くため既報(7)(8) と同様の手法 を用いた，すなわち， $S_{F}$ の評価に際しては，火炎進行度 $\left(R_{A} / R_{C}\right)^{3}$ が約 0.018 となる，ほぼ同一の体積燃焼割合時 の火炎面のみを解析対象とした (図 4 参照)。ここで， $R_{A}$ および $R_{C}$ は各々火炎断層写真から得られる既燃部断面 積およひ燃焼室容積の等価半径を表す.

なお，火炎断層写真の解析対象は，その対称性より燃焼室中央より上方のみとした．また， 10 組の乱流火炎 面から得られる解析点総数は, 各撮影条件で 3800 程度となる.

次に, 既報(7) と同様の手法で, 得られた 2 次元画像から火炎面面積変化率に基づく火炎伸長を推定した. 火炎 伸長 $K$ は，火炎面面積 $A$ の時間変化量として一般的には次式のように定義される ${ }^{(14)}$.

$$
K=1 / A \cdot \mathrm{d} A / \mathrm{d} t
$$

ここで, 外向きに伝ぱする球状層流火炎での火炎伸長 $K_{l}$ は, 式(2)を基に時系列で変化する火炎半径 $r_{f}$ を用いて 次式で表される ${ }^{(15)}$.

$$
K_{l}=2 / r_{f} \cdot\left(\mathrm{d} r_{f} / \mathrm{d} t\right)
$$

乱流火炎の火炎伸長 $K_{T}\left[=1 / A_{T} \cdot \mathrm{d} A_{T} / \mathrm{d} t\right]$ 考えた場合, 火炎構造の 3 次元性により層流火炎ほど単純ではない(16). 本研究では, 表 1 に示寸ように比較的低 $R e_{l}$ 場を対象としていること, 二枚の画像の時間間隔および解析点間隔 が短いことから， $K_{T}$ における乱流火炎面の要素面積の微小変化量 $\mathrm{d} A_{T}$ を, 図 3 に示すように, 連続する火炎面 1 と 2 の各火炎面の要素面積 $A_{1}$ と $A_{2}$ を， $S_{F}$ を求める時に使用したそれぞれ隣接する解析点の距離 $l_{1}$ と $l_{2}$ を用い て次式で得られると仮定し求めた.

$$
\mathrm{d} A_{T}=A_{2}-A_{1}=l_{2}^{2}-l_{1}^{2}
$$

\section{3. 実験結果および考察}

\section{$3 \cdot 1$ 火资形状特性}

図 4 に, ファン回転速度 $1000 \mathrm{rpm}\left(\mathrm{N}_{2} \& \mathrm{Ar}: u^{\prime} / S_{L 0}=1.4, \mathrm{He}: u^{\prime} / S_{L 0}=1.8\right)$ での当量比 $\phi=0.5$ の窒素, アルゴンとヘリ 


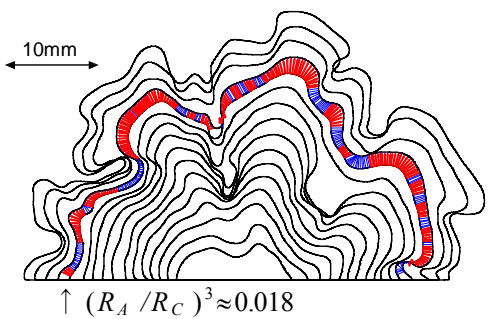

(a) $\mathrm{N}_{2}[\mathrm{H} 05-25 \mathrm{~N}]$

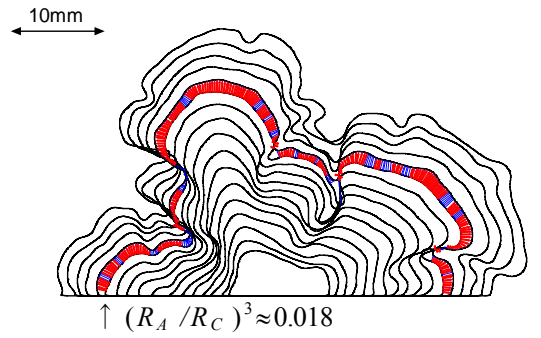

(b) $\operatorname{Ar}[\mathrm{H} 05-25 \mathrm{~A}]$
- :Vector on Positive Curvature

—:Vector on Negative Curvature

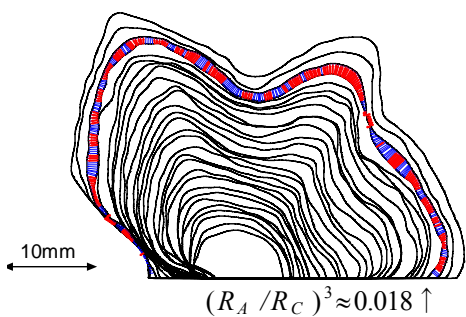

(c) $\mathrm{He}[\mathrm{H} 05-25 \mathrm{H}]$

Fig. 4 Temporal evaluations of upper part of flame front contours for turbulent flames $\left(\phi=0.5, u^{\prime} / S_{L 0}=1.4\right.$ for $\mathrm{N}_{2}$ and $\mathrm{Ar}, u^{\prime} / S_{L 0}=1.8$ for $\mathrm{He}$, Images photographed every $\left.0.5 \mathrm{~ms}\right)$

ウムを希釈ガスとした場合の乱流火炎面の時系列に変化する等值面の一例をそれぞれ示寸．図 4 中，ベクトルを 示した火炎面は， $\left(R_{A} / R_{C}\right)^{3}$ が約 0.018 である。また太赤線は正曲率形状部分での火炎伝ぱベクトルを，細青線は 負曲率部分であることを示す。

図 4 より，希釈ガスが窒素とアルゴンの場合は，概ね同等の火炎形状を有することがわかる．しかし，へリウ ムの場合, 窒素等に比べて相対的に乱れ強さ $u^{\prime} / S_{L 0}$ が大きいにもかかわらず，火炎面の凹凸のスケールが大きく のっペりとした火炎形状になっていることがわかる. これは, 表 1 に示寸ように, $\phi=0.5$ では, 希釈ガスがヘリ ウムの場合のみルイス数 $L e$ が 1 より大きく,$L e<1$ の混合気に比べて相対的に火炎面形状が安定化するためであ ると推測できる(14). さらに，ヘリウムの場合には，他に比べて等值面の間隔が狭いことから，火炎の伝ぱ速度が 他に比べて遅いと推測できる.

図 5 に, 解析した結果の一例として, 図 4 と同じく $\phi=0.5$ の各希釈ガスの混合気に対して, 各 10 枚の火炎を 解析した, 予熱帯厚さで無次元化した火炎曲率 $\eta_{0} r$ の確率密度関数 $\mathrm{pdf}$, および層流燃焼速度で無次元化した換算 局所火炎変位速度 $S_{F} / S_{L 0}$ を示寸. なお， $\eta_{0}$ は $\left(a_{0} / S_{L 0}\right)$ で定義されるが，表 1 から $a_{0}$ 值がヘリウム混合気の場合に 他と比べ 5 倍程度大きいことから，ヘリウムの場合[図 5(c)]は横軸のスケールが他と変えてある.

図 5 から, 比較的乱れの弱い $u^{\prime} / S_{L 0}=1.4\left(\mathrm{He}: u^{\prime} / S_{L 0}=1.8\right)$ にもかかわらず, いずれの混合気においても, 既報(7)(8) と同様に層流燃焼時と異なり $\eta_{0} / r$ および $S_{F} / S_{L 0}$ が広い範囲に分布していることがわかる. さらに，窒素とアルゴ ンの場合には， $\phi=0.5$ においては，正曲率側，すなわち未然混合気側に凸な形状部分の方が $S_{F} / S_{L 0}$ が若干大きくな る傾向に分布し，両者は概ね同様な分布を示寸傾向にある，一方，ヘリウムの場合，他と異なり正曲率と負曲率 側での $S_{F} / S_{L 0}$ の分布に大きな傾向の差異が観察できないことがわかる．これは，上述したようにルイス数の影響 が現れていると推測できる. なお，他の当量比においても，窒素とアルゴンは同等の傾向を示した．これら $S_{F}$ の值が広く分布する現象は, 既報 (7)(8)でも議論したように, 少なくとも図 4 の様なしわ状もしくは連続的な火炎が

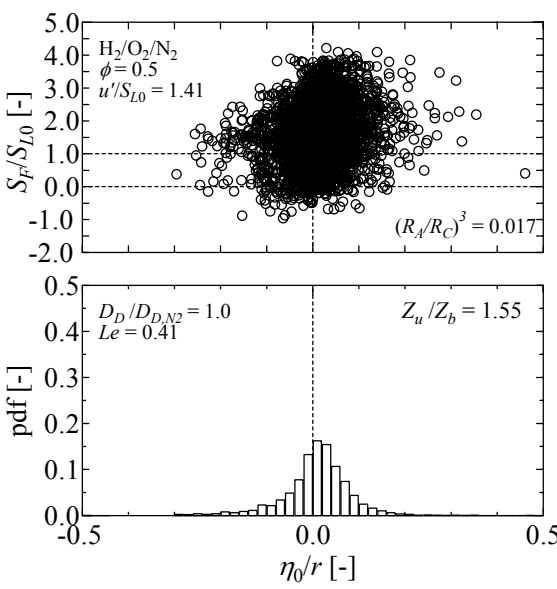

(a) $\mathrm{N}_{2}[\mathrm{H} 05-25 \mathrm{~N}]$

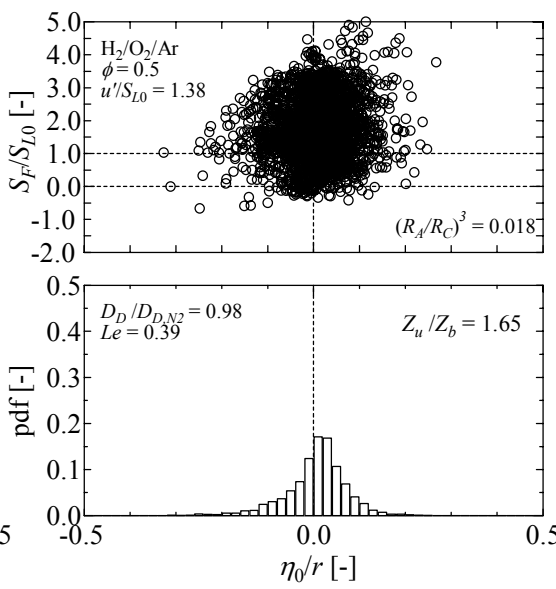

(b) $\operatorname{Ar}[\mathrm{H} 05-25 \mathrm{~A}]$

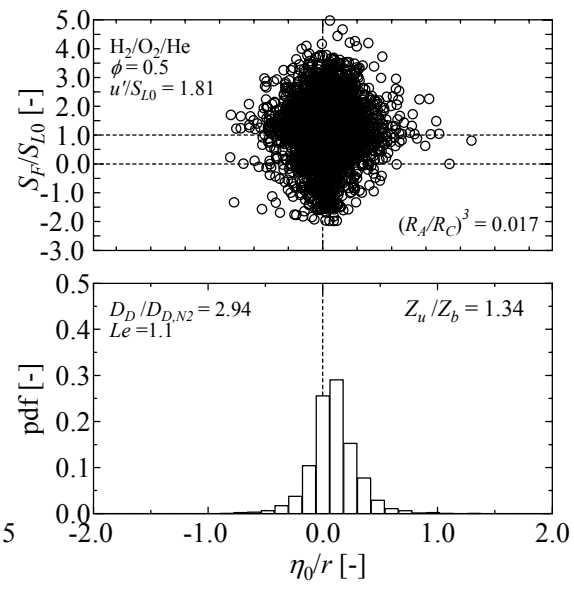

(c) $\mathrm{He}[\mathrm{H} 05-25 \mathrm{H}]$

Fig. 5 PDF of $\eta_{0} / r$ and distribution of $S_{F} / S_{L 0}$ for turbulent flames $\left(\phi=0.5, u^{\prime} / S_{L 0}=1.4\right.$ for $\mathrm{N}_{2}$ and $\mathrm{Ar}, u^{\prime} / S_{L 0}=1.8$ for He) 


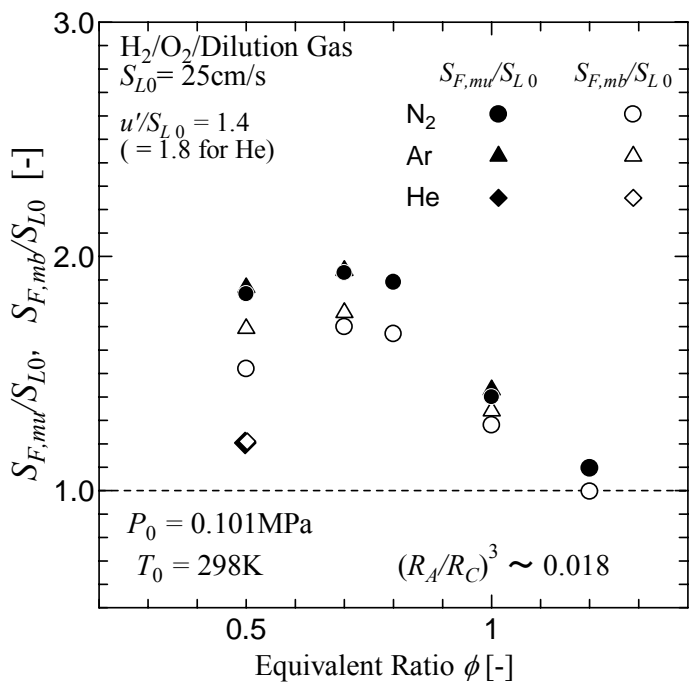

Fig. 6 Variation of $S_{F, m u}$ and $S_{F, m b}$ with $\phi$ and dilution gas types $\left(u^{\prime} / S_{L 0}=1.4\right.$ for $\mathrm{N}_{2}$ and $\mathrm{Ar}, u^{\prime} / S_{L 0}=1.8$ for $\left.\mathrm{He}\right)$

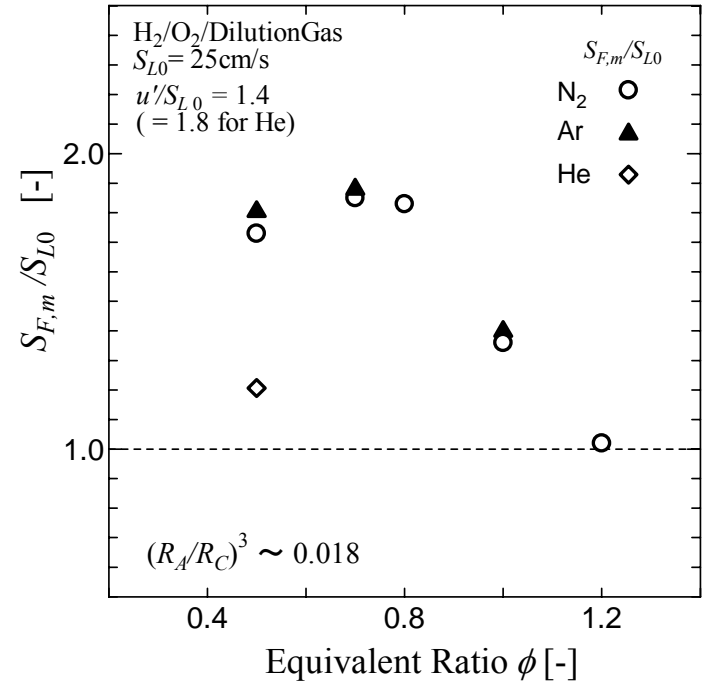

Fig. 7 Variation of $S_{F, m}$ with $\phi$ and dilution gas types $\left(u^{\prime} / S_{L 0}=1.4\right.$ for $\mathrm{N}_{2}$ and $\mathrm{Ar}, u^{\prime} / S_{L 0}=1.8$ for $\left.\mathrm{He}\right)$

存在するような比較的乱れの弱い領域では，火炎面の局所燃焼速度は層流燃焼速度であるとする従来の多くの乱 流燃焼速度モデル(17) と矛盾寸る. また, この $u^{\prime} S_{L 0}=1.4$ 程度の乱流火炎でも $S_{F}$ 值の広い分布が観測されることは, 比較的弱い乱れ強度から乱流場の非定常性が局所燃焼特性に現れることを示唆している.

また図 5 中に示す $Z_{u} / Z_{b}$ 值は，正曲率側と負曲率側の解析点の個数比を表す．図 5 から，Leが 1 より大きなへ リウムの場合には他より $Z_{u} / Z_{b}$ 值は小さくなるものの, $Z_{u} / Z_{b}$ 值は希勫ガスによらず 1 より大きく, 負曲率より 正曲率の解析点の個数は多いことがわかる. 他の条件でも同様の傾向を示した. これは 2 次元での解析ではある が，水素一酸素一希釈ガス混合気でも未燃混合気側に凸な部分の燃焼特性がより乱流火炎全体の燃焼特性に影響 を及ぼす可能性があること(7)(8)を示している.

なお図 5 中， $S_{F} / S_{L 0}$ が負の值を示すものが存在する. これは， $S_{F}$ が式(1)より伝ぱ速度 $V_{F}$ に基づく值で， $V_{F}$ が 負の值であったことに起因する． $V_{F}$ が負の值を示すものが存在することは，上述のように，等方的な定常乱れ場 であっても，厳密な微小火炎要素の局所燃焼速度の算出には，火炎面近傍の流れ場の考慮が必要であることを示 唆している。特に，本実験範囲では，図 5(c)からわかるように, ヘリウムを希釈ガスとした場合, $S_{F} / S_{L 0}$ が負の 值を示寸割合が他より多く全体の解析点の 1 割近くに達する。これは，図 4 で観測されたようにへリウムの場合 には火炎伝ぱ速度が遅く乱れ等の外的因子の影響を受けやすいためであると推測できる.

\section{$3 \cdot 2$ 換算局所火炎変位速度特性}

図 6 に, $u^{\prime} S_{L 0}=1.4\left(\mathrm{He}: u^{\prime} / S_{L 0}=1.8\right)$ で測定した $S_{F}$ の正曲率側の平均值 $S_{F, m u}$ および負曲率側の平均值 $S_{F, m b}$ を $S_{L 0}$ で無次元化した值と $\phi$ の関係を示寸．なお，既報(7)の窒素を希釈ガスとした $S_{L 0}$ を $25 \mathrm{~cm} / \mathrm{s}$ に揃えた $\phi=0.8$ と 1.2 の 結果も合わせて示寸. また, $S_{F, m u}$ および $S_{F, m b}$ は, 対象となる解析点数に基づく単純平均であり, 火炎面形状に著しく 凹凸が発生したり, 火炎移動距離が大きくなると, 真の值より誤差が増大することが推測できる ${ }^{(18)}$.

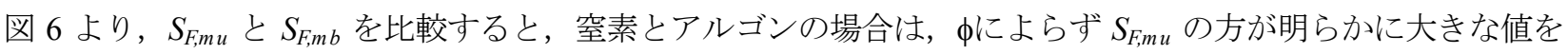
示寸．一方， $\phi=0.5$ のみであるがヘリウムの場合には，両者に差異は見られない，さらに，窒素とアルゴンの場

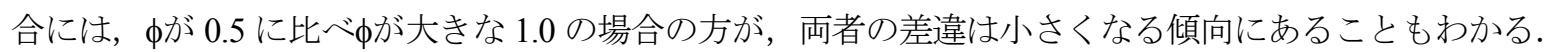

これは, 3.1 節での火炎形状の観測結果や既報 ${ }^{(8)}$ で然料の種類の差異に着目し議論したように, 希釈ガスの差異 に起因するルイス数の効果 ${ }^{(14)}$ によるものと推測できる. 表 1 に示すように，本実験範囲では，へリウム混合気 $(\phi=0.5)$ の Le は 1 より大きく, 窒素とアルゴンの場合には, Le は 1 より小さく, $\phi$ が1に近づくと大きくなる傾向 にある. すなわち, $L e<1$ の場合は拡散一熱的不安定性により，未燃混合気側に凸な火炎面部分の燃焼速度が既燃 ガスに凸な部分に比べて相対的に増大し, 火炎面の凹凸を発達させる傾向となる.一方，Le>1 の場合は基本的に は火炎面の凹凸を安定化する方向に作用する. したがって, 図 6 に示すように, Le が大きな混合気ほど $S_{F, m u}$ と $S_{F, m b}$ 


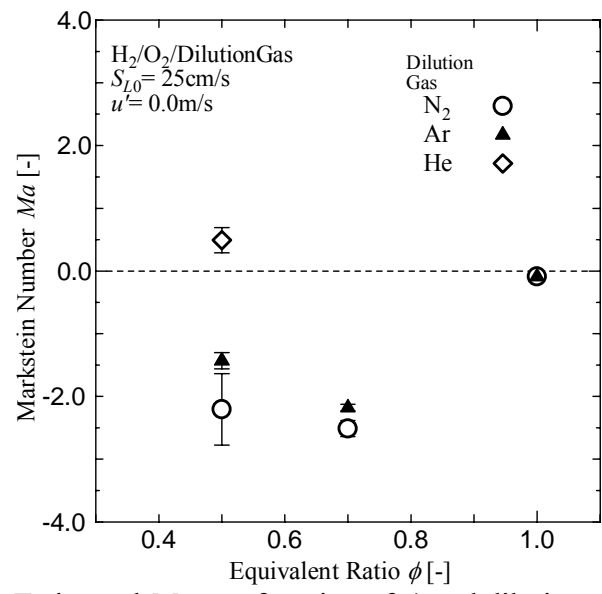

Fig. 8 Estimated $M a$ as a function of $\phi$ and dilution gas types

の差異が減少する傾向が観察されたと推測できる.

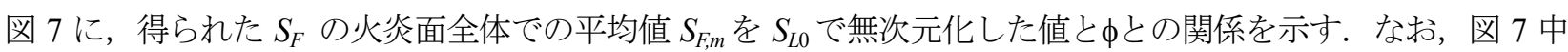
に，図 6 と同様に既報 ${ }^{(7)}$ の結果を合わせて示寸，図 7 から，窒素とアルゴンの場合は，同一の乱れ特性值のもと

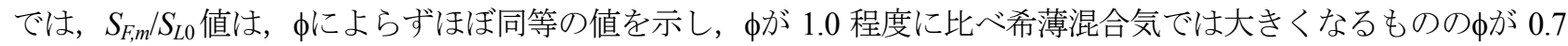
と 0.5 では大きな差異がないことがわかる. 一方，ヘリウムの場合は， $\phi=0.5$ のみであるが，他の希釈ガスに比べ

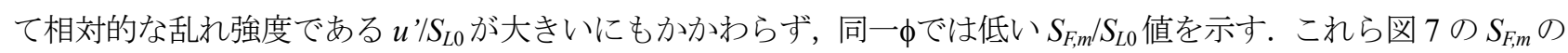
結果は, 図 2 で観察された乱流燃焼速度特性とよい一致を示す。したがって, 既報(7)(8)で検討した燃料の差異のみ ならず，希釈ガスの異なる混合気でも， $S_{F}$ は上述のように局所燃焼速度と同值ではないが強い相関関係にある值 と考えられることから, 局所燃焼速度特性が乱流燃焼速度特性を決定寸る重要な因子であることは明らかである.

次に，この乱流火炎の局所燃焼速度特性に影響を与える因子の一つとして，各混合気が層流燃焼場で固有する 燃焼速度の火炎伸長に対する感度を表す Markstein 数を推定し, 乱流火炎の局所燃焼速度特性との関係について 議論する.

\section{$3 \cdot 3$ 乱流火炎の局所燃焼速度に及ぼす Markstein 数の影響}

伸張や曲率を有する層流火炎面の燃焼速度がその度合いにより変化することが，多くの漸近的解析や実験研究

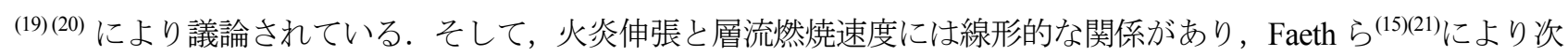
式が外向きに伝ぱする球状層流火炎に対して提案されている.

$$
S_{L \infty} / S_{L l}=1+M a \cdot K a_{l}
$$

ここで， $S_{L \infty}$ は火炎伸張がないときの層流燃焼速度 $\left(S_{L 0}\right.$ に相当する值)， $S_{L l}$ は伸張を受けているときの層流燃焼速 度 $\left[=\left(\rho_{b} / \rho_{u}\right) \cdot\left(d r_{f} / d t\right)\right], K a_{l}$ は火炎伸長度を表す Karlovitz 数 $\left[=K_{l} \cdot\left(a_{0} / S_{L l}{ }^{2}\right)\right], K_{l}$ は式(3)の火炎伸張 $\left[=1 / A \cdot d A / d t=\left(2 / r_{f} \cdot d r_{f} / d t\right)\right], A$ は火炎面要素面積, $r_{f}$ は球状伝ぱ層流火炎の平均半径, $M a$ は Markstein 数で ある. したがって, 基本的には時系列に変化する $r_{f}$ を求めることにより, 式(5)から Ma が推定可能である(7)(8).

図 8 に, 式(5)から求めた $M a$ と㠶関係を示寸. 図 8 から, 希釈ガスがアルゴンと窒素の場合, $M a$ は, 本実験

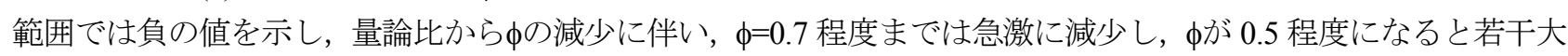
きくなる傾向を示寸ことがわかる，一方，ヘリウムの場合， $\phi=0.5$ のみであるが， $\mathrm{Ma}$ は，他の希釈ガスに比べ大 きな值を示し，正の值を有することがわかる．ここで，式(5)は，同一 $K a_{l}$ では， $M a$ が大きいほど燃焼速度が低下 する関係を示す．この式(5)の関係から，各希勫ガスにおいて，図 8 の $M a$ の傾向は，図 6 や 7 の $S_{F}$ 傾向と相関が あるよう見える，そこで，両者の関係を次に検討する。

ここで，Ma は層流火炎を対象に得られたものであるが，その形状および伸長の作用の類似性から，少なくと も乱流火炎のうち未燃混合気側に凸な正曲率を有する火炎形状部分の局所燃焼速度と伸張との関係を評価する指 針となると考えられる，そこで，図 9 に，層流火炎から得られた $M a$ と $u^{\prime} / S_{L 0}=1.4 （ \mathrm{He}: u^{\prime} / S_{L 0}=1.8 ）$ の乱流火炎か ら得た正曲率部分の $S_{F}$ の平均值 $S_{F, m u}$ の関係を示寸. なお図 9 には, 既報 (7)(8) の水素一メタンと水素一プロパンの 


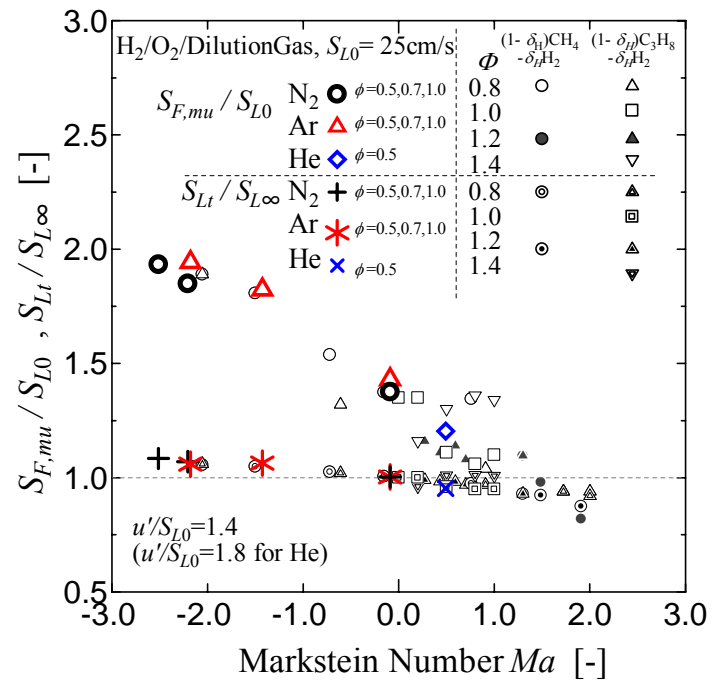

Fig. 9 Relationship among $M a, S_{F, m u} / S_{L 0}$ and $S_{L t} / S_{L \infty}$ estimated by $M a$.

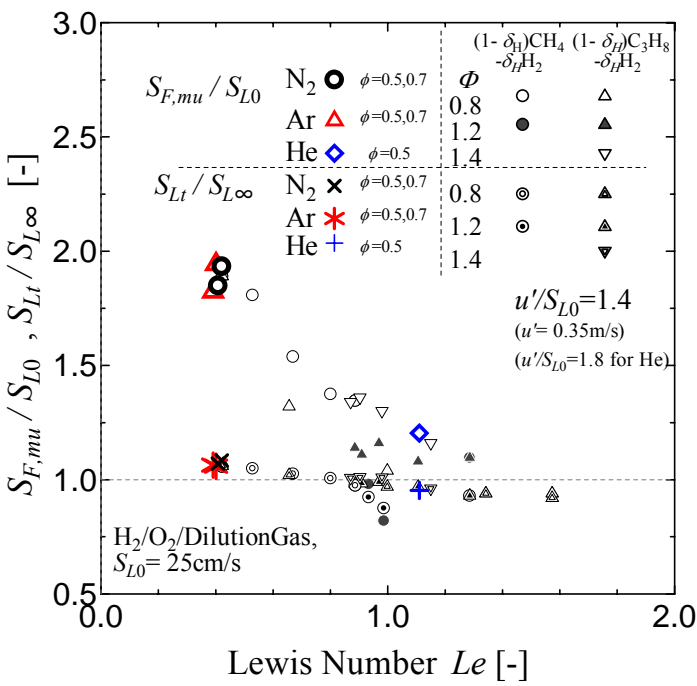

Fig. 10 Relationship among Le, $S_{F, m u} / S_{L 0}$ and $S_{L t} / S_{L \infty}$ estimated by $M a$.

二成分燃料混合気の結果も合わせて示寸ままた図 9 中，二成分燃料混合気のФは，燃料中の各炭素および水素分 子数を基にした総合当量比 ${ }^{(7)(8)}$ を表す.

図 9 から，希釈ガスに起因する $M a$ の差異と $S_{F, m u} / S_{L 0}$ の関係が，これまでに明らかにした燃料の種類の差異に 起因した $M a-S_{F, m u} / S_{L 0}$ の関係(7)(8) と同様であることがわかる.すなわち, $M a$ が負から正へと大きくなると, $S_{F, m u} / S_{L 0}$ が概社比例的に低下寸る．これは，上述の式(5)が，同一 $K a_{l}$ では， $M a$ が大きいほど然焼速度が低下寸る関係にあ ることと一致する，すなわち，窒素，アルゴンやへリウムで希釈した水素一酸素混合気でも，定性的には層流火 炎から得られた $M a$ が乱流火炎の局所燃焼速度特性と良い相関関係にあることがわかる.

次に，上述のように局所燃焼特性と関連性を有するルイス数との関係を検討するために, $S_{F, m u} / S_{L 0}$ と Le との関 係を図 10 に示寸，なお，図 10 には，図 9 と同様に二成分燃料混合気の結果 ${ }^{(7)(8)}$ も合わせて示寸.

図 10 から, $L e-S_{F, m u} / S_{L 0}$ の関係にも $M a$ と同様に良い相関関係にあり, Le の増大とともに $S_{F, m} / S_{L 0}$ が概ね線形 的に減少することがわかる。.また，図 10 から，Le が 1.0 付近の二成分燃料混合気において, 図 10 の Maに比べ て，不連続性が若干観察される，このことと，Le は $\phi=1.0$ で不連続となることを考えあわすと，混合気を構成す る成分に因らず乱流火炎の局所燃焼速度特性を整理するには, Markstein 数の方が適していると考えられる.

最後に, 乱流火炎の燃焼速度特性を整理する上で重要な因子の一つである $M a$ が，乱流火炎の局所燃焼速度に 定量的にはじれだけ影響を与えるか検討を試みる。ここでは，既報(7) と同様に式(5)を乱流火炎一適用する手法に より, $M a$ を求めた外向きに伝ぱする球状層流火炎と同じく, 乱流火炎のうち正曲率かつ正伸長の火炎部分が有 する Karlovitz 数を被った場合の燃焼速度の変化量 $S_{L t} / S_{L \infty}$ を, $M a$ の乱流火炎への効果量として次式で推定する.

$$
S_{L \infty} / S_{L t}=1+M a \cdot K a_{t}
$$

ここで， $S_{L t}$ は式(5)で得た $M a$ に基づく正曲率で正伸長を有する乱流火炎の局所燃焼速度の推定值であり，Ka $a_{t}$ は 乱流火炎の局所火炎特性を考慮した Karlovitz 数で次式から求める.

$$
K a_{t}=1 / n \cdot\left(\sum^{n} K_{T} \cdot a_{0} / S_{F}^{2}\right), \quad \text { at } 1 / r>0 \& K_{T}>0
$$

式(7)中, $n$ は正曲率で正伸長を有する火炎要素(解析点)の数, $K_{T}$ は式(4)より推定した乱流火炎の微小火炎要素の 表面積変化 $\left[=1 / A_{T} \cdot \mathrm{d} A_{T} / \mathrm{d} t\right]$ に基づく火炎伸長である.

図 9 および 10 中に, 式(6)より乱流火炎 $\left(\mathrm{N}_{2} \& \mathrm{Ar}: u^{\prime} / S_{L 0}=1.4, \mathrm{He}: u^{\prime} / S_{L 0}=1.8\right)$ の正曲率かつ正伸長火炎部に対して 推定した $S_{L t} / S_{L \infty}$ を示寸. なお, 本実験では $K_{T}$ 值は, $u^{\prime} / S_{L 0}=1.4$ では $80 \sim 1501 / s$ 程度, $u^{\prime} / S_{L 0}=1.8$ では約 $601 / s$ で ある. 
図 9 と 10 から, 既報(7)(8) で明らかにした燃料の種類のみならず, 希釈ガスの種類に因らず, $M a$ に基づく $S_{L t} / S_{L \infty}$ は，MaおよびLeが大きいほど小さくなる傾向にあり，定性的には乱流火炎から得られた $S_{F, m u} / S_{L 0}$ との相関関係

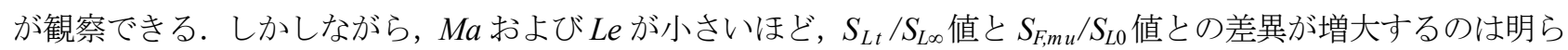
かである. すなわち, 大きい $M a$ およびLeを有する混合気の乱流火炎ほど, 特に $M a>0$ および $L e>1$ では, Markstein 数の効果が，少なくとも乱流火炎面のうち正伸長を有する未燃混合気側に凸な火炎部分の燃焼速度の变化におい て支配的な因子であると推測できる.一方， $M a<0$ および $L e<1$ で $M a$ および $L e$ が小さい乱流火炎の局所燃焼 速度の変化には，他の支配因子が存在すると考えられる，その支配因子の一つとして，熱拡散より物質拡散が支 配的な $L e<1$ で両者の差異が顕著になることから，火炎面に凹凸が発生することにより作用する選択拡散効果 ${ }^{(14)}$ が考えられる．ここで, 分子拡散特性に着目 ${ }^{(0)(8)}$ 寸ると, 水素とヘリウムは分子量が他の窒素やアルゴンさらに は酸化剂の酸素より小さく拡散速度が大きい。したがって，上述のように乱流燃焼場を支配する未燃混合気側に 凸な火炎部分には，選択拡散効果により拡散速度が相対的に大きな水素やへリウムが拡散する. 例えば，水素一 酸素一アルゴンや窒素混合気の場合, 希薄の $\phi=0.5$ や 0.7 では $L e<1$ であり物質拡散の効果が支配的となり, 不足 成分である水素が，この未燃混合気側に凸な火炎部分に相対的に多く拡散するため，この部分の燃焼速度が増加 する. そのため図 9 や 10 のように, $L e<1$ では, $S_{F, m u} / S_{L 0}$ と $S_{L t} / S_{L \infty}$ の差異が大きくなる傾向が観察されると推測 できる. なお，乱流燃焼場から得られた $S_{F}$ には，式(5)や(6)で考慮した式(2)に基づく火炎表面積の変化にともな う火炎伸長に加え, 層流然焼場にはない例えば $\mathrm{u}^{\prime} / \lambda_{\mathrm{g}}$ のガス流動による火炎伸長も作用している，ここで， $\lambda_{\mathrm{g}}$ はテ イラーの微細尺度で, ファン回転速度 $1000 \mathrm{rpm}$ では $u^{\prime} / \lambda_{\mathrm{g}}$ は $1901 / \mathrm{s}$ 程度である.

以上本研究から, 真の局所燃焼速度特性の評価には, 火炎面近傍の流れや乱流火炎の三次元性の考慮 ${ }^{(13)(16)(22)}$ が必要であるが，もし図 9 のような $M a$ と局所燃焼速度特性と何らかの相関関係が存在すると, Ma は実験的にも 解析的にも得ることが可能なため, $M a$ に基づく乱流火炎の局所燃焼速度予測モデルを構築できる可能性がある. さらに, 既報(10)で局所燃焼速度に基づく乱流燃焼速度モデルを提案しているが，本研究は，水素一酸素一希釈ガ ス混合気のみならず多様な混合気に対応した乱流燃焼速度モデル(10)の構築に発展しうる可能性もある.

一方，希釈ガスや燃料の種類によらず， $M a<0$ または $L e<1$ の混合気のような，乱流火炎の局所燃焼速度特性 を, 層流火炎の伸長の燃焼速度への効果を表す Markstein 数だけでは定量的には説明できない混合気条件が存在 することを明らかにできた。

\section{4. 結 論}

層流燃焼速度 $S_{L 0}$ を $25 \mathrm{~cm} / \mathrm{s}$ に揃えた当量比 $\phi=0.5 \sim 1.0$ の水素一酸素一希釈ガス混合気において, 希勫ガスを一般的 な窒素に加えて, アルゴンおよびヘリウムを対象にし, 二次元火炎断層写真撮影法を用いて乱れ強さu’゙ $0.35 \mathrm{~m} / \mathrm{s}$ (He: $0.47 \mathrm{~m} / \mathrm{s}$ ) での乱流火炎の換算局所火炎変位速度 $S_{F}$ を定量化し検討した. 得られた主な知見を以下に示す.

(1) 希釈ガスがヘリウムの場合は, $\phi=0.5$ のみの検討であるが, 他の希釈ガスに比べて相対的な乱れ強さが大きい

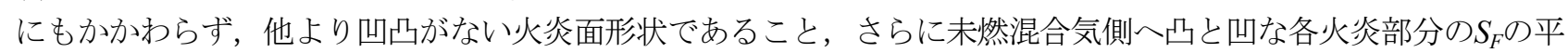
均值に差異がないことが観察された。この現象は，ヘリウム混合気が他の希釈ガス混合気よりルイス数が大きい ことに因ると推察できた.

(2) 乱流火炎から得られた $S_{F}$ の平均值 $S_{F, m}$ は, ヘリウムの場合 $(\phi=0.5)$ は, 同一 $\phi$ 窒素やアルゴンの場合に比べ著

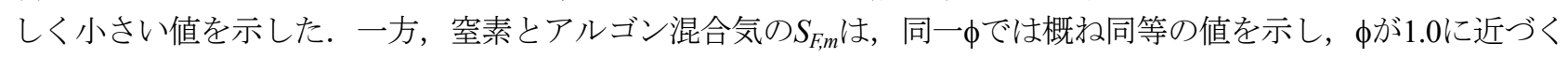
と急激に低下寸る傾向を示寸ことがわかった，さらに，これら $S_{F, m}$ の傾向は，希釈ガスの種類によらず，これら混 合気の乱流燃焼速度特性とよい一致を示寸ことが明らかになった。

(3) 希釈ガスの種類を変化させた混合気でも, 外向きに伝ぱする球状層流火炎から得たMarkstein数Maは, 乱流火炎の 未燃混合気側に凸な火炎部分の $S_{F}$ の平均值である $S_{F m u}$ と良い線形的な相関関係にあることが確認できた. また, 不足成 分に基づくルイス数Leも $S_{F m u}$ と概㸚線形的な関係にあることがわかった.

（4）最後に，層流火炎から得られた $M a$ が乱流然焼場でどれだけ局所燃焼速度に影響を与えるか定量的に検討するた め, $M a$ をもとに乱流火炎の正伸長かつ正曲率を有する火炎部分の燃焼速度 $S_{L t}$ の推定を試みた. その結果, 希釈力゙スに

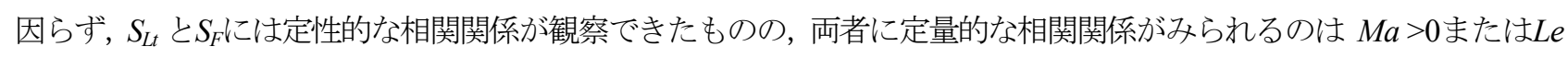
>1の混合気条件であることを明らかにした。 


\section{謝 辞}

終わりに，本研究において九州大学名誉教授・城戸裕之先生に貴重なご意見を頂いた．また，本研究の実験を 行うにあたり, 九州大学大学院工学府学生・高本英明君, 愛媛大学大学院理工学研究科学生・藤田侑士君にご協 カいただいた。ここに記し, 謝意を表す.

\section{文献}

(1) WE-NET summary of annual reports (1994), http://www.enaa.or.jp/WE-NET/index.html (参照日 2011 年 8 月 1 日).

(2) 古谷博秀, 濱純, 高橋三餘, “ArF エキシマレーザによる水素一酸素ーアルゴン混合気の着火・火炎核成長過程の 実験的研究”，日本機械学会論文集 B 編，Vol.61, No.590(1995), pp.3470-3476.

(3) Chiesa, P., Lozza, G., Mazzocchi, L., "Using Hydrogen as Gas Turbine Fuel”, Journal of Engineering for Gas Turbines and Power, Vol.127(2005), pp.73-80.

(4) Kishore, V.R., Muchahary, R., Ray, A., Ravi, M.R., "Adiabatic burning velocity of $\mathrm{H}_{2}-\mathrm{O}_{2}$ mixtures diluted with $\mathrm{CO}_{2} / \mathrm{N}_{2} / \mathrm{Ar}^{\text {", }}$ International Journal of Hydrogen Energy”, Vol.34(2009), pp.8378-8388.

(5) 井上雅弘, 中原真也, “水噴霧による水素の燃焼制御法に関する研究”, 水素エネルギーシステム, Vol.34, No.3 (2009), pp.23-30.

(6) 城戸裕之, 橋本淳, Barat D., 西垣雅司, 岡本秀樹, “乱流燃焼速度に及ぼす不活性ガスの影響”, 日本機械学会論文 集 B編， Vol.65, No.640 (1999), pp. 4138-4143.

(7) Nakahara, M., Shirasuna, T., and Hashimoto, J., "Experimental Study on Local Flame Properties of Hydrogen added Hydrocarbon Premixed Flames”, Journal of Thermal Science and Technology, Vol.4, No.1(2009), pp.190-201.

（8）中原真也，橋本淳，白砂貴盛，月川正善，“水素添加プロパン予混合乱流火炎の局所燃焼速度特性に関する実験的 検討”，日本機械学会論文集 B編，Vol.75, No.760 (2009), pp.2550-2557.

(9) Bird, R.B., Stewart, W.E., and Lightfoot, E.N. "Transport Phenomena", (1960), John Wiley \& Sons., p.554-591.

(10) 城戸裕之, 中原真也，“選択拡散効果を考慮した乱流燃焼速度の整理” ，日本機械学会論文集 B編，Vol.63，No.614 (1997), pp.3477-3483.

(11) Lewis, B., and von Elbe, G., Combustion, Flames, and Explosion of Gases, 3rd ed. (1987), pp.333-361, p.389, Academic Press.

(12) Babkin, V. S., Babushok, V. I., and Suyushev, V. A., Dynamics of Turbulent Gas Combustion in a Closed Volume, Combustion, Explosion, and Shock Waves, Vol.13, No.3 (1978), p.291-295.

(13) Furukawa, J. and Williams, F. A., Flamelet Effects on Local Flow in Turbulent Premixed Burning Flames, Combustion Science and Technology, Vol.170 (2003), pp. 1835-1858.

(14) Williams, F. A., Combustion Theory 2nd, The Benjamin/Cummings, (1985), p.349.

(15) Know, S., Tseng, L.-K., and Faeth, G. M., Laminar Burning Velocities and Transition to Unstable Flames in $\mathrm{H}_{2} / \mathrm{O}_{2} / \mathrm{N}_{2}$ and $\mathrm{C}_{3} \mathrm{H}_{8} / \mathrm{O}_{2} / \mathrm{N}_{2}$ Mixtures, Combustion and Flame, Vol.90(1992), pp.230-246.

(16) Tanahashi, M., Sato, M., Shimura, M., T. Miyauchi. T., "DNS and Combined Laser Diagnostics of Turbulent Combustion", Journal of Thermal Science and Technology, Vol. 3, No. 3(2008), pp. 391-409.

(17) Andrews, G.E., Bradley, D. and Lwakabamba, S.B., Turbulence and Turbulent Flame Propagation-A Critical Appraisal, Combustion and Flam, Vol.24 (1975), pp.285-304.

(18) Renou, B., Boukhalfa, A., Puechiberty, D., and Trinité, M., Local Scalar Flame Properties of Freely Propagating Premixed Turbulent Flames at Various Lewis Numbers, Combustion and Flam, Vol.123(2000), pp.507-521.

(19) Markstein, G.H., Non-steady flame Propagation, (1964), p.22, Pergamon, New York.

(20) Peters, N., Turbulent Combustion, (2000), p.95, Cambridge University Press.

(21) Know, O.C., and Faeth, G. M., Flame/Stretch Interactions of Premixed Hydrogen-Fueled Flames: Measurements and Predictions, Combustion and Flam, Vol.124(2001), pp.590-610.

(22) Gashi, S., Hult, J., Jenkins, K.W., Chakrabort, N., Kaminski, C.F., Curvature and wrinkling of premixed flame kernels comparisons of OH PLIF and DNS data, Proceedings of Combustion Institute, Vol.30 (2004), pp. 809-817. 